\title{
ASPECTOS INTERESSANTES OBSERVADOS NA MEIOSE DE ALGUNS HEMIPTEROS
}

8. de Toledo Pina Jor.

Professor de Zoologia, Anatomia e Fisiologia da Escola Superior de Agricultura "Luiz de Queiroz", da Universidade de Săo Paulo

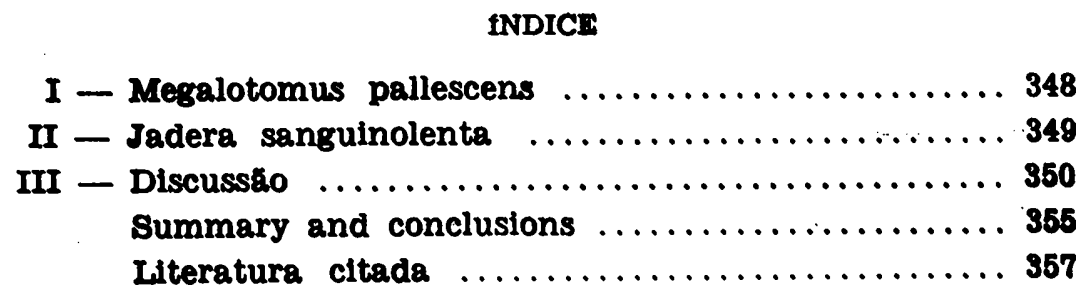


Estudando a meiose do Coriscideo Megalotomus pallescens (Stal) e do Corizideo Jadera sanguinolenta (Fabr.) (*), encontrei dois aspectos que mereceram especial atenção e que porrisso constituem o objeto deste artigo. $O$ primeiro refere-se ao sexo-cromossomio e o segundo aos microcromossomios.

\section{I - MEGALOTOMUS PALLESCENS (Figs. 1-9)}

O número haplóide de cromossómios da presente espécie e $7+\mathbf{X}$. $O$ cromossómio sexual, depois da m-tétrade, é o menor elemento da placa metafásica. Incontra-se no círculo formado pelos autossómios (Fig. 8) ou no centro, com os microcromossomios, que ocupam sempre essa posição. Uma das tétrades autossomais é bem maior do que as outras.

O sexo-cromossômio - elemento, no início da historia dos espermatocitos primários, apresenta-se com uma forma alongada e um contóno mais ou menos irregular, sempre fora da área ocupada pelo novelo cromático. Dal para a sintzese ele val regularizando o seu aspecto, exibindo de maneira mais ou menos clara uma fenda longitudinal e uma constriçáo mediana. (Fig. 1). Na fase paquitene o sexo-cromossomio mostra-se ainda bem alongado e em virtude da constriçăo mediana, quase sempre encurvado ou dobrado. (Fig. 2). Quando em posiçåo favorável, mostra-se nitidamente fendido no sentido longitudinal. (Fig. 2, ao lado). Desse momento em diante ele se contrai, para adquirir o aspecto tetradiforme (Fig. 3), que conserva até a metáfase.

Na diacinese e na metáfase o sexo-cromossómio só se distingue dos autossomios pelo seu menor tamanho, pois também ele se apresenta fendido no sentido do comprimento e provido da caracteristica cinturinha mediana. (Figs. 8 e 9). Divide-se equacionalmente pela constriçăo transversal.

Nas metáfases secundárias o cromossomio sexual se encontra em geral na zona equatorial, com uma forma arredondada ou ligeiramente alongada segundo o eixo do fuso, passando, na anáfase, sem se dividir, para um dos pólos.

Os m- cromossómios - Os microcromossómios sâo um pouco menos heteropicnóticos que o cromossômio sexual, apresen-

(*) Devo ao meu prezado colega, Dr. Oscar Monte, do Instituto Biológico de S. Paulo, a determinaçáo das duss espécies estudadas neste trabalho. 
tando-se porisso menas coloridbs que aquele nas fases que precedem a diacinese. Desde a saida do núcleo do estado confuso já eles se delxam reconhecer como dols corpúsculos arredondados, palidos e bem individualizados. (Fig. \$). O que há de mais interessante com respelto aos microcromossomios e o seu comportamento relativamente ao sexo-cromossomio. assim que eles, embora geralmente se encontrem bem separados entre si e do cromossomio sexual (Figs. 4 e 5), foram repetidamente observados nas promixldades deste ultimo e ate mésmo em contacto com ele. As vores apenas um se encontra junto ao cromossomio sexual, ficando o outro a pequena distancia. A posiçáo das microcromossomios com relaçáo ao sexo-cromossomio pode ser qualquer, conforme se llustra com a Fig. 7.

Formaça das tetrades - A formaçăo das tétrades merece alguma atença, por se processar de uma maneira bem diferente da que será descrita para a especie seguinte.

A situaç̌̃o confusa do núcleo em estado difuso (Fig. 3) logo se vai aclarando pelo aparecimento de areas cromossomais distintas. Essas áreas săo de aspecto reticular e extremamente irregulares. (Fig. 4). Dentro em pouco elas se vão tornando cada vez mais nitidamente delimitadas, apresentandose alongadas, porém ainda muito confusas. Mais tarde 0 aspecto dessas areas vai ficando inteligivel, pols nelas se val podendo distinguir dois filamentos irregulares bastante afastados entre si e ligados por conectivos transversais de espessura variável. (Fig. 5). Desste ponto em diante as cordర́es laterais se vko espessando e aproximando e os conectivos desaparecendo, para darem origem as tétrades com a forma caracteristica com que tem elas sido inumeras vezes descritas em outras especies. (Fig. 6).

\section{II - JADERA SANGUINOLENTA (FIgs. 10-21)}

O Corizideo que constitui o objeto deste artigo possui espermatogónios com 13 cromossomios, ou sejam, 10 autossomios, 2 microcromossomios e 1 sexo-cromossomio. (Fig. 10). Dentre os autossómios se destaca um par de elementos multo majores que os demais. Diversas anafases espermatogonais foram encontradas, nas quais se pode observar, que, conforme a regra, os cromossomios encurvam-se para o polo a que se dirigem. (Fig. 11).

Os espermatocitos primários exibem 6 tétrades mais 0 cromossomio $X$. (Fig. 12). A tétrade maior multas vezes se apresenta dobrada como na Fig. 13. 
o sexo-cromossómio, na primeira divisão, divide-se como se fósse uma tétrade. Na segunda ele passa sem se dividir para um dos pólos. De regra se encontra na frente de uma das placas (precessáo) e raramente ao lado (sincronismo). Sucessáo fol observada ocasionalmente e assim mesmo so em anáfases muito avançadas. (Fig. 15). Já nas metáfases secundárias a posiça mais trequente do sexo-cromassomio é fora do plano equatorial e mesmo bem longe desse plano. (Fig. 14).

o que achel de mais interessante na meiose desta espécle fol a formaçáo das tétrades. Vimos que na espécle precedente o núcleo em estado difuso se resolvia num certo número de áreas cromossomais muito confusas e correspondentes as futuras tétrades, as quais se lam tornando cada vez mais distintas e iam aos poucos delxando distinguir nelas dois cordres paralelos bem afastados. Dal para diante os cordరes longitudinais cada vez mais se aproximavam e se espessavam ao mesmo tempo que os conectivos transversais desapareciam e logo a primitiva área irregular e confusa se via transformada numa tétrade tipica de Hemiptero.

Na presente espécie as cousas se passam de maneira multo diferente. Ao deixar o estado confuso o núcleo se apresenta intelramente tomado por um novelo cromático bem colorido e uniforme. (Fig. 16). Asse aspecto ele conserva até que os bivalentes comecem a se tornar individualmente distinto. istes aparecem entro formados por dois longos cordoes separados em toda a sua extensăo, menos nas extremidades. (Figs. 17 e 18). $O$ bivalente maior, em virtude do seu comprimento, apresenta-se em geral recurvado ou dobrado das mais variadas maneiras e muitas vezes, devido a aproximaça de suas extremidades, que se acham voltadas para o mesmo lado, toma a forma de um duplo anel. Aas poucos os cordoes reunidos pelas extremidades se vio encurtando e depois engrossando, para originarem as tétrades diacinéticas, que em nada diferem das descritas para outras especies. (Figs. 19 e 20). A tetrade maior pode apresentar-se direita ou dobrada pela abertura mediana, que permanece até a metáfase. (Fig. 21).

\section{III - DIscUssAO}

Cromossómio sexual - Na primeira das espécies estudadas neste trabalho (Megalotomus pallescens) fol possivel observar, com suficiente clareza, que o sexo-cromossómio é a principio um elemento alongado, dividido no sentido longitudinal e provido de uma constriçáo mediana, condiçoes estas que lhe văo 
dar, mais tarde, ùm aspecto tìpicamente tetradiforme. Allás, essa configuração já tem sido assinalada em inúmeras espécies e se acha claramente representada nas recentes figuras de SCHRADER (1946) referentes ao Pentatomídeo Brachystethus rubromaculatus Dallas. Esse autor, porém, considera a incisão longitudinal como sendo uma incisão terceária, com o que não estamos de acôrdo. A incisão longitudinal, pela qual os cromatideas muitas vezes se separam completamente na diacinese para depois novamente se juntarem na metáfase, é simplesmente uma incisăo primária, isto é, uma incisáo, através da qual o sexo-cromossómio, que não se encontra pareado, se divide, como os autossómios na mitose, no sentido do comprimento. (Cf. PIZA 1946). Essa incisão só será utilizada para regenerar a dicentricidade do cromossómio sexual, transformando-se, desse modo, na constriçăo transversal através da qual se dará a separação dos cromatideos na primeira divisão dos espermatócitos da geraçăo seguinte. Embora curto, năo resta dúvida alguma de que o cromossómio $X$ de Megalotomus pallescens se divide segundo a constriçăo transversal.

Uma particularidade digna de nota do sexo-cromossômio da outra especie (Jadera sanguinolenta) está no seu comportamento na segunda divisáo. Af êle aparece com uma forma arredondada e náo se orienta, ficando geralmente fora do plano equatorial, tal como foi descrito relativamente ao Diactor bilineatus. (PIZA 1945). Em vista disso a sua posiçăo na anáfase corresponde à precessão, tendo sido observado em sucessáo e assim mesmo muito próximo de uma das placas, apenas em pourcas anáfases já muito avançadas. A causa dêsse comportamento talvez se encontre na entrada dos cinetocores em inatividade, o que faz com que os cromatídeas sexuais não se abram, na prometáfase da segunda divisáo, como se dá com os autossomios, para só mais tarde regenerarem a dicentricidade confuntamente com os cromatídeos autossomais.

Em face dos dados até agora obtidos, penso poder resumir - comportamento do sexo cromossómio dos Hemipteros cujos machos săo do tipo XO, da seguinte maneira:

a) $O$ cromossómio $X$ apresenta-se na metáfase primária bem dividido no sentido longitudinal e sem constrição transversal. Orienta-se com as suas extremidades no plano do equador e os seus cromatídeos se separam pelo plano de divisão. (Euryophthalmus, Protenor). Na segunda divisăo o cromossômio, provido de um cinetocore ativo em cada extremidade, orienta-se com o seu eixo longitudinal paralelamente ao eixo do fuso, passando, sem se dividir, para um dos pólos. Passa integralmente para êsse pólo (Protenor?) ou deixa uma de 
suas extremidades no polo oposto, devendo, porisso, mais tarde, regenerar sua dicentricidade. (Euryophthalmus).

b) $O$ cromossómio $X$ apresenta-se na metáfase primária com um aspecto quadripartido, isto é, provido da uma incisão longitudinal e de uma constrição transversal. Orienta-se com o seu comprimento segundo o eixo do fuso - o que se deve provàvelmente ao fato dos cinetocores não haverem ainda se dividido - e se divide transversalmente. (Corizus hyalinus, Megalotomus pallescens). Na metáfase secưndária 0 sexo-cromossômio, tornado dicêntrico por uma divisão longitudinal iniciada no cinetocore, orienta-se perpendicularmente ao plano equatorial e sem perda de qualquer extremidade, passa indiviso para um dos pólos. (Megalotomus pallescens). Ou, distendendo-se entre os dois pólos, passa só para um dêles, perdendo, porém, para o outro, um dos cinetocores. (Corizus hyalinus). Nesse caso o sexo-cromossómlo tem que regenerar a dicentricidade na telófase secundária.

c) O cromossómio sexual, arredondado ou muito curto, orienta-se como as tétrades e se divide transversalmente na primeira divisão. Na segunda, devido à inatividade do cinetocore, permanece monocêntrico, não se orienta, fica fora do plano equatorial e muitas vezes bem longe dêsse plano, passando para a célula que se forma do lado em que se encontra. $\mathrm{Na}$ telófase secundária regenera a dicentricidade ao mesmo tempo que os cromatídios autossomais. (Jadera sanguinolenta, Diactor billineatus).

d) O sexo-cromossómio na primeira divisão se orienta no equador da célula com o seu eixo longitudinal paralelamente ao eixo do fuso. Passa integralmente para um dos pólos ou alongando-se entre as placas anafásicas deixa um dos cinetocores no pólo oposto. Neste último caso torna-se dicentrico na prometáfase da segunda divisão, comportando-se nesta como os autossómios. A sua divisão corresponde pois a uma divisáo longitudinal. (Pachylis laticornis, $\left({ }^{*}\right)$ Pachylis Pharaonis).

(*) Examinando mais alguns exemplares dessa espécie encontrei com muita frequência o cromossômio $X$ alojado na parte central do círculo formado pelos autossômios nas metáfases primárias e bem assim em forma de fuso alongado na anáfase, tal como foi descrito para $P a-$ chylis pharaonis. (Cf. PIZA, 1946). 
Comportamento dos microcromossômios. - Num trabalho anteriór admiti a possibilidade dos microcromossómios se originarem do sexo-cromossómio, considerando-os como extremidades centricas dêste último, que se estabilizaram como estruturas permanentes. (Cf. PIZA 1946). Em apóio dessa idéia apontei a heteropicnose dos microcromossómios e o seu modo de pareamento, duas particularidades que os aproximam do sexocromossomio. Agora quero assinalar a conduta dos microcromossomios relativamente ao cromossómio sexual, o que vem em favor da hipótese aventada. Realmente, constatou-se em Megalotomus pallescens, que os microcromossômios muitas vezes procuram alojar-se nas proximidades do cromossômio $\mathbf{X}$, o que náo pode deixar de indicar uma certa afinidade entre essas duäs sortes de cromossómios. Aliás, se os microcromossómios se originam do sexo-cromossômio da maneira que foi descrita no trabalho acima citado, temos af uma base constitucional responsável pela afinidade funcional désses elementos. E visto que os mịcrocromossómios conseguiram, pela evoluçăo, estabelecer-se como individualidades autónomas, o que se observa nesta espécie deve apenas significar uma afinidade residual, que em outras desapareceu. Segundo se estabeleceu para o Tityus bahiensis (PIZA 1943), quando dois fragmentos cêntrico săo perfeitamente equivalentes êles se comportam como um par homólogo, não se associando aos cromossômios de que provieram, contanto que êstes também se achem presentes aos pares. Mas, se dois fragmentos do mesmo cromossomio se encontram em presença do cromossómio homólogo daquele que se fragmentou, com êle se paream na meiose. O mesmo se dá quando dois cromossómios diferentes e livres têm os respectivas homólogos fundidos num elemento complexo. (PIZA 1944). Parece-me seja êsse o motivo que permitiu aos microcromossómios dos Hemipteros libertarem-se da influência atrativa do sexo-cromossómios. A origem do mecanismo X1X.2. . XnY $\mathrm{X}^{1} \mathrm{X}^{2}$. $\mathrm{X}^{\mathrm{n}} \mathrm{X}^{1} \mathrm{X}^{2}$.. $\mathrm{X}^{\mathrm{n}}$ pela perda progressiva de extremidades de um primitivo $\mathrm{X}$, parece-nos igualmente provável, conforme pretendemas discutir numa outra ocasião.

Outros aspectos. - $O$ modo de formação das tétrades em Megalotomus pallescens a partir de áreas cromossomais confusas e inanalisáveis que aos poucos se vão conformando para produzir os aspectos diacinéticos e metafásicos típicos dos Hemípteros, em nada nos ajuda a compreender as rélações mútuas dos cromossomios envolvidos no processo. Relativamente à Jadera sanguinolenta as cousas se passam de maneira bem diferente, 
oferecendo-nos a melhor das oportunidades para uma análise detalhada daquilo que realmente ocorre entre os cromossomios que vêm de deixar a fase confusa da história do núcleo. De fato, as fases que precedem ao núcleo difuso e particularmente a fase paquitene năo nos deixam dúvida alguma acêrca da existência de uma parassinapse, isto é, de que os cromossómios se tenham pareado no sentido do seu comprimento. Nesta espécle, no contrário do que se verifica na espécie precedente, os cromossómios no núcleo difuso conservam o seu aspecto fllamentar formando um frouxo novelo que enche completamente a cavidade nuclear. Esse novelo resulta da distensăo e separação dos cromossómios que se encontravam pareados e estreitamente unidos nos paquinemas da fase precedente. Em um trabalho anterior (PIZA 1945), estudando em Diactor bilineatus certos aspectos dos bivalentes antes e depois do estado confuso, tive a impressão de que os componentes de cada par se separavam completamente, permanecendo, porém, unidos pelas extremidades. Jadera vem agora nos dar uma bela demonstração de que realmente assim é. As figuras 17 a 21 mostram de maneira bem clara que os cromossómios deixam o estado confuso do núcleo pareados apenas pelas extremidades. $\mathbf{E}$ como é por essas extremidades que as tétrades se prendem ao fuso, segundo se pode constatar numa série completa de estádios intermediários que văo daí à metáfase, fica inteiramente abolida a idéla de uma inserçáo difusa, cuja inexistência, aliás, já foi suficientemente provada. Entretanto, os aspectos fixados nas figuras 17-21 poderiam levar o observador a pensar sejam os cromossómios de Jadera mediocêntricos e se tenham separado no núcleo difuso a comecar pelos cinetocores, para se conservarem até a metáfase unidos por ambas as extremidades. Essa questão já foi suficientemente discutida em outro trabalho, falando contra uma tal interpretaçăo, além de outros, o fato da dicentricidade observada nos cromossomios espermatogoniais desta e de diversas outras espécles, nos cromossómios somáticos de Anasa sp. (PIZA \& ZAMITH 1946) e nos cromossómios sexuals de várias èspécies investigadas,

Mostrado, como foi, que os bivalentes de Jadera se apresentam desde $o$ inicio inteiramente abertos em sua parte mediana, os quiasmas, se existirem, devem se ter acumulado desde muito cedo nas extremidades. Se porém năo tiver havido formaçăo de quiasmas, seremos então forçados a apelar para uma forte atraçáo entre os cinetocores com o fim de compreender a permanência das pontas em contacto, o que aliás já foi sugerido em outro trabalho. 


\section{SÜMMAR̈Y AND CONCLÚSIONS}

Particular aspects of the meiosis of two species of Hemiptera, namely Megalotomus pallescens (Stal) (Coriscidae) and Jadera sanguinolenta (Fabr.); (Corizidae) are described and discussed in this paper.

\section{Megalotomus pallescens}

This species has primary spermatocytes provided with 7 autosomal tetrads plus a single sex chromosome. The $X$ is smaller than the autosomes and may be found either in the periphery of the circle formed by the autosomal tetrads or in the center together with the m-tetrad which always occupies this position.

The $\mathbf{X}$ chromosome - In the primary spermatocytes this element, which is tetradiform, orients itself parallelly to the spindle axis and divides transversely by its median constriction. In the secondary spermatocytes it passes undivided to one pole.

The m-chromosomes - These chromosomes have been frequently found in close association with the sex chromosome in nuclel wich have passed the diffuse stage, a fact which was considered as affording some evidence in support of the idea developed by the present writer in another paper with regard to the origin of the $\mathrm{m}$-chromosomes from the sex chromosome.

Formation of tetrads - Tetrads appear at first as irregular areas of reticular structure, becoming later more and more distinct. Then, two chromosomal strands very loose and irregular in outline, connected whit each other by several transverse filaments, begin to develop in each area. Growing progressively shorter, thicker and denser, these strands soon give origin to typical Hemiptera tetrads,

\section{Jadera sanguinolenta}

Spermatogonia of this species have 13 chromosomes, that is, 10 autosomes, $2 \mathrm{~m}$-chromosomes and one sex chromosome, one pair of autosomes being much larger than the rest. Chromosomes move toward the poles with both ends looking to them. 
Primary spermatocytes show 6 tetrads and a single $X$.

The sex chromossome in the first division of the spermatocytes divides as if it was a tetrad, passing undivided to one pole in the second rivision. In the latter it does not orient, being found anywhere in the cells. Its most common situation in anaphase corresponds therefore to precession.

Tetrads are formed here in an entirely different way : the bivalents as they become distinct in the nuclel which came out of the diffuse stage they appear in form of two thin threads united only at the extremities, an aspect which may better be analized in the larger bivalent. Up from this stage the formation of the tetrads is a mere process of shortening and thickening of both members of the pair. Due to the fact that the paired chromosomes are well separated from each other throughout their entire lenght, the author concluded that chiasmata, if present, are accumulated at the very ends of the bivalents. If no chiasmata have been at all formed, then, what holds together the corresponding extremities must be a strong attraction developed by the kinetochores. If one interprets the bivalents represented in the figures 17-21 as formed by four chromatids paired by one of the ends and united by the opposite one, then the question of the diffuse attachment becomes entirely disproved since it is exactly by the distal extremities that the tetrads later will be connected with the poles. In the opinion of the present writer the facts referred to above are one of the best demonstration at hand of the continuity of the paired threads and at the same time of the dicentricity of Hemiptera chromosomes.

In view of the data hitherto collected by the author the behavior of the sex chromosome of the Hemiptera whose males are of the XO type may be summarized as follows:

a) The sex chromosome in the primary metaphase appears longitudinally divided, without transverse constriction. It is oriented with the extremities in the plane of the equator and its chromatids separate by the plane of division. (Euryophthalmus, Protenor). In the second division the sex chromosome, provided as it is with an active kinetochore at each end, orients itself with its lenght parallelly to the spindle axis and passes undivided to one pole (Protenor?), or loses to the other pole a centric end (Euryophthalmus). In the latter case it has to become dicentric by means of a longitudinal spliting beginning at the kinetochore. 
b) The sex chromosome in the primary metaphase is tetradiform, that is, it is provided with a longitudinal split and a median transverse constriction. Orients with its length parallelly to the spindle axis (what is probably due to the kinetochores being not yet divided) and divides transversely. (Corisus hyalinus, Megalotomus pallescens). in the secondary metaphase the sex chromosome which turned to be dicentric in consequence of a longitudinal spliting initiated in the kinetochore, orients perpendicularly to the equatorial plane and without losing anyone of its extremities passes undivided to one pole (Megalotomus). Or, distending between both poles passes to one side, in which case it loses one of its ends to the other side. (Corkus hyalinus).

c) The very short sex chromosome in the first division of the spermatocytes orients in the same manner as the tetrads and divides transversely. In the second division, due to the inactivity 0 the inetochore, it remains monocentric and motionless anywhere in the cell, finishing by being enclosed in the nearer nucleus. In the secondary telophase it recuperates its dicentricity at the same time as the autosomal chromatids. (Jadera sanguinolenta, Diactor bilineatus).

d) The sex chromasome in the first division orients in the equador with its longitudinal axis parallelly to the spindle axis passing integrally to one pole or, distending itself between the anaphase plates, loses one of its ends to the opposite pole. In this case it becomes dicentric in the prometaphase of the second division, behaving in this division as the autossomes. It thus divides longitudnally. (Pachylis laticornis, Pachylis pharaonis).

\section{LITERATURA CITADA}

PIZA, S. de Toledo, Jor. 1943 - Melosis in the male of the brazilian scorpion Tityus bahiensis. Rev. de Agr.. 18 : 249-276.

PIZA, S. de Toledo, Jor. 1944 - A case of spontaneous end-toend permanent union of two non homologous chromosomes in 
the brazilian scorpion Tityus bahiensis accompanied by irregularities in pairing. Rev. de Agr. 19: 133-147.

PIZA, S. de Toledo, Jor. 1945 - Estudos citológicos em Hemipteros da Familia Coreidae. An. Esc. Sup. Agr. "Luiz de Queiroz" 2: 119-148.

PIZA, S. de Toledo, Jor. 1946 - Nota prévia sobre a melase de Corizus (Liorhyssus) hyalinus (Fabr.) (Hemiptera-Corizidae). An. Esc. Sup. Agr. "Luiz de Queiroz" 3 : 141-148.

PIZA, S. de Toledo Jor. e A. Zamith, 1946 - Provas adicionais da dicentricidade dos cromossómios dos Hemípteros. An. Esc. Sup. Agr. "Luiz de Queiroz" 3 : 89-97.

SCHRADER, F. - 1946 - The elimination of chromosomes in the meiotic divisions of Brachystethus rubromaculatus Dallas. Biol. Bul. 90 (1) : 19-31. 




Fig. 1 - Espermatócito primário na fase zigotene, vendo-se no interior do núcleo o cromossômio $X$ com a sua característica constrição transversal. (x2500)

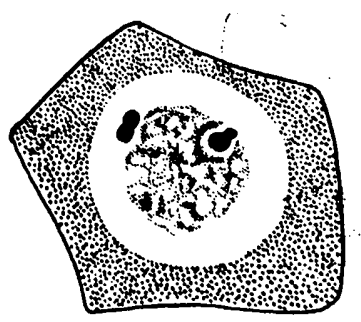

Fig. 3 - Espermatócito primário com o núcleo em estado difuso. Note-se o cromossômio $X$ (o que se acha mais para fora) com o seu aspecto tetradiforme. (x2500)

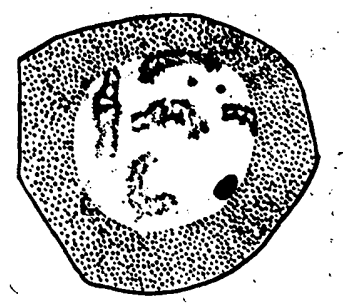

Fig. 5 - Estado das tétrades mais adeantado do que 0 representado na Fig. 4, vendo-se

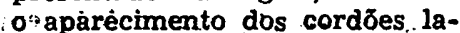
terais nas diversas áreas do núcleo (x2500)

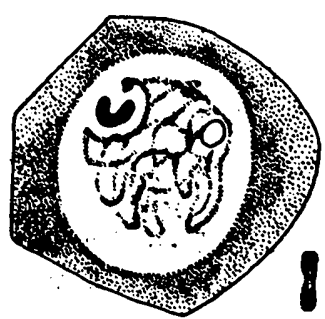

Fig. 2 - Espermatócito primário na fase paquitene. Ao lado o sexo cromossômio com aspecto tetradiforme, tal como se pode observar nessa fase. (x2500)



Fig. 4 - Espermatócito primário em cujo núcleo as tétrades começam a se tornar distintas sob a forma de áreas ainda muito difusas. $O$ cromossômio $\mathrm{X}$ e os dois microcromossômios acham-se representados. (x2500)

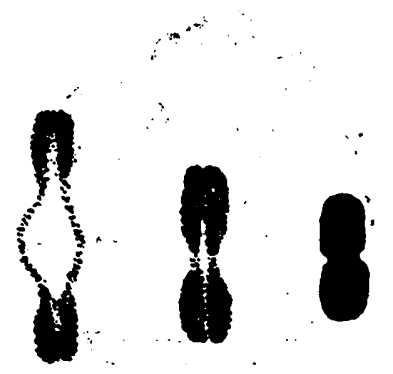

Fig. 6 - As últimas fases: da formação das tétrades 

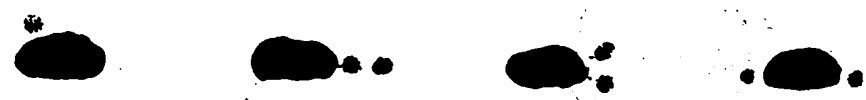

Fig. 7 - Diversas figuras mostrando as relações dos microcromossômios com o cromossômta $\mathbf{X}$

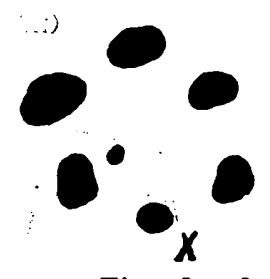

Figs. 8 e 9 - Vista polar e lateral da metáfase primária (x3500)

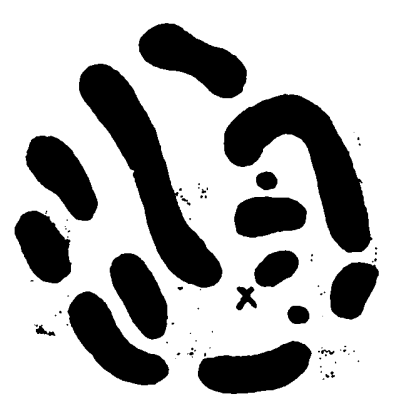

Fig. $10^{\circ}-$ Métáfase espermatogoniaf $(x 4000)$

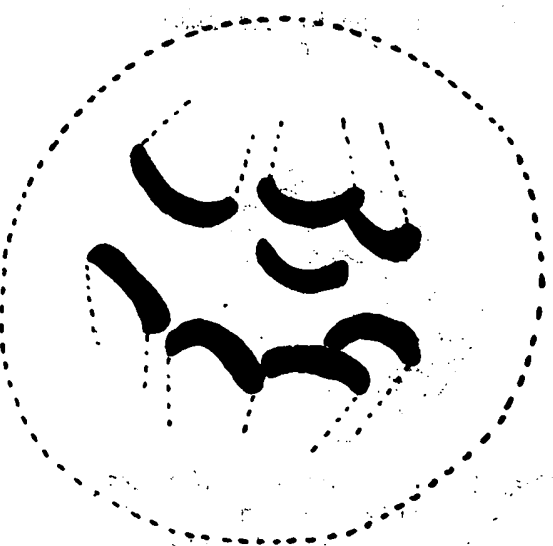

-Fig. 11 - Espermatogônio em anáfase $(x 6000)$ 



Figs. 12 e 13 - Espermätócitos primários em metáfase ( $x 3200)$
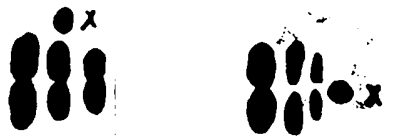

Fig. 14 - Vistas laterais da metáfase secundária mostrando a posição do cromossômí $X$. (2500)


Fig. i5 - Anáfases secundárias mostrando o comportamento do cromossômio X. (x2500)

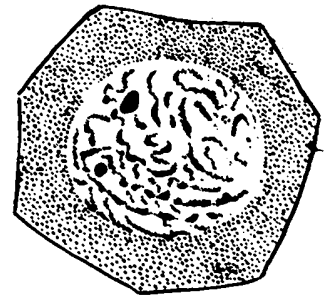

Fig. 16 - Espermatóito primicrio logo após o estado canfuso do núcleá $(\mathbf{2 0 0 0 )}$ 

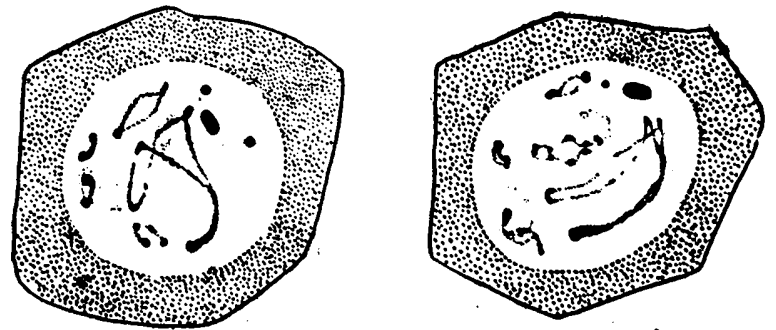

$$
\therefore
$$

Figs. 17 e 18 - Espermatócitos primários com tếtrades ainda muito novas, numa fase que corresponde perfeitamente à fase diplotene das meioses or todoxas (x2200)


Figs. 19 e 20 - Dois aspectosmais avançados da formação das tétrades $(x 2200)$


Fig. 21 - Dois aspectos communs do bivalente maior ha far "se." correspondente à represemtada nas figs. 19 e 20 